\title{
Insights of HBV Pathogenesis and Emerging Clinical Therapies for HBV Induced HCC Patients for a Better Prognostic Outcome
}

\author{
Reshmi Chatterjee ${ }^{1}$ Abhisek Mitra ${ }^{2 *}$ \\ ${ }^{1}$ E.S.I Hospital, Belur, West Bengal, India, ${ }^{2}$ University of Texas MD Anderson Cancer Center, Houston, TX, USA
}

\section{A B S TR A C T}

Chronic hepatitis $\mathrm{B}(\mathrm{CHB})$ virus infection is a global epidemic and a majorcause of hepatocellular carcinoma (HCC). Approximately, 400 million people with 1.5 million Americans are chronically infected with this virus and around 1 million deaths from HBV annually have been estimated. High serum viral load has been detected between $75-80 \%$ of HCC patients. Epidemiological studies revealed that there are geographical variations in the incidence rate of hepatitis $B$ virus genotype and subgenotypes. Furthermore, HBV induced HCC has a direct correlation with the recurrent genomic integration of this virus and cross-talk of its oncogenic protein HBV $x$ $(\mathrm{HBx})$ with different cellular signaling pathways. With the help of an extensive pathological study, whole genome sequencing and molecular insights of HBV induced HCC patients, suitable medications providing high-genetic barrier to resistances aremade available. These medications can prevent HCC by inhibiting viral replication, modulating the immune response or both. The evolution of drugs with superior efficacy and less toxicity are providing important tools for clinicians to reduce HBV related HCC. This review sheds new perspective on molecular insight of HBV life cycle and clinical updates to treat sustained virus infection and associated cancers.
Access this article online

Website:

http://nepjol.info/index.php/AJMS

DOI: $10.3126 /$ ajms.v6i4.11884

Key words: HBV, Epidemiology, HCC, peg-IFN- $\alpha$, Tenofovir, Entecavir, Clevudine, Clinical trials

\section{INTRODUCTION}

Hepatitis B is a systemic infection with major pathology in the liver. Caused by HBV, a DNA virus with human as the only reservoir, it is a serious worldwide public health problem and major cause of chronic hepatitis, cirrhosis and hepatocellular carcinoma. Of the estimated 2 billion peoplewho have serological evidence of past or current HBV infection, more than 400 million people are chronic carriers of whom there is $\sim 1$ million deaths annually from HBV related diseases. ${ }^{1-4}$

HBV is usually transmitted by parenteral route and contact with infected body fluids such as blood, semen and saliva. ${ }^{5}$ In comparison to low endemic areas where transmission is in adulthood which is self-limited in most, in highly endemic countries it is transmitted early in life by vertical or horizontal mode increasing the chronicity rate ${ }^{6}$ Chronic hepatitis $\mathrm{B}(\mathrm{CHB})$ is the major etiological factor of HCC globally with more than one half of HCC patients being chronic carriers. ${ }^{7}$ The prevalence of $\mathrm{CHB}$ is highly variable, ranging from $0.01 \%$ in United states to $20-30 \%$ in some Pacific Island Nations. ${ }^{6}$ From virological point of view, $\mathrm{CHB}$ is defined as the active viral replication with sustained hepatitis B surface antigen for more than 6 months with or without $\mathrm{HBe}$ antigen $(\mathrm{HBeAg}){ }^{8}$

The availability of an efficacious and safe vaccine since 1982 with implementation of effective vaccination programmes in various countries, ensued in a significant decrease in the incidence of acute as well as chronic HBV infection. But because of the high morbidity and mortality rate among chronic carriers worldwide, hepatitis B still remains a disease of considerable importance.

Knowledge of the epidemiology of HBV will be an initial direction towards prevention and treatment of this global infection.It is known that prevalence of chronic HBV 
infections varies according to geographical locations. Related to this, it has been categorized as high, intermediate and low endemicity. ${ }^{5}$ This geographical variability showed a positive correlation with the risk of $\mathrm{HBV}$ induced HCC in patients. ${ }^{5,9}$ In the pathogenesis of HCC, virological factors contribute an important role. The complex life cycle of HBV initiates with viral entry into the cell by binding to $\mathrm{Na}^{+}$taurocholate cotransporting polypeptide(NTCP)on the surface and being endocytosed..$^{10}$ Thereafter the virus modulate hepatocytes by genomic integration and its stages of replication. Appropriate understanding of the HBV life cycle can help in the development of novel antiviral drugs and design effective therapeutic measures. This review highlights important aspects of HBV induced HCC such as epidemiology, life cycle and current clinical therapies.

\section{Epidemiology of HBV induced HCC}

The prevalenceof $\mathrm{HBV}$ varies markedly in different parts of the world. The main clinical marker of HBV whichindicates chronic or acute infection, prevalence as well as endemicity is HBsAg. A huge load of HBsAg infection was recorded in all sub-Saharan African regions, East Asia and to a lesser extent, in Oceania and Andean Latin America. ${ }^{11}$ In other regions such as Tropical Latin America, Central Latin America, North America and Western Europe throughout all age groups the prevalence was below $2 \% .{ }^{11}$ The development of HCC has been strongly associated with chronic HBV infection since 1970 's. ${ }^{12}$ Similar studies showed that in high incidence areas such as east Asia and sub-Saharan Africa,more than $80 \%$ patients who developed HCC patients were seropositive for HBsAg. ${ }^{12}$

Molecular insight of HBV pathogenesis to induce HCC The HBV is classified as the type species of the Orthohepadnavirus, though the Hepadnaviridae family of viruses has not been assigned to a viral order. ${ }^{13}$ The virion or the virus particle of HBV consists of an outer lipid envelope and an icosahedral nucleocapsid core composed of protein; the nucleocapsid encloses the viral DNA and a DNA polymerase that has reverse transcriptase activity similar to retroviruses. ${ }^{14}$ Also this virus has filamentous and spherical bodies lacking a core, which are composed of the surface antigen HBsAg. The genome of the HBV has several distinctive features which contain:(a) a partially double stranded DNA, (b) circular DNA conformation, (c) dependence on a reverse transcription step in the viral cycle of replication, and (d) persistence of the viral genome in infected cells as either integrated forms, or as episomal form. ${ }^{15}$

Recent studies help us to provide a comprehensive idea about the mechanism of integration of HBV DNA into host genome, and further possible rearrangements for its oncogenicity. ${ }^{16} \mathrm{HBV}$ replicates productively in the liver (unintegrated in host cell DNA) and the infectious virions circulate in the plasma along with an excess of $\mathrm{HBsAg}$ (Figure 1). The HBV genome has recombinant proficient areas based on the distribution of DNA junctions. ${ }^{17}$ All the integrated viral genomes are defective at least around the cohesive end region, particularly within the $\mathrm{X}$ gene. Experimental evidence suggests that capsids with mature genome interacts with nucleoporin 153 in nuclear basket to get inside the nucleus. ${ }^{18}$ The partial DNA strand of the genome is synthesized and a complete double-stranded DNA covalently closed circular molecule (cccDNA) is formed in the nucleus. ${ }^{19}$ During the initiation of infection of the liver by HBV, both linear DNA and rcDNA are converted into cccDNA. ${ }^{20}$ The cccDNA is transcribed into mRNA by host cell RNA polymerase II. The mRNAis translated into structural proteins (envelope and core proteins) and non-structural proteins (enzymes) in the cytoplasm. Within the core, the negative sense DNA strand is synthesized by reverse transcriptase. The plus-strand is not synthesized prior to the virion release, as a repair damage mechanism to produce a fully dsDNA during initiation of a subsequent round of infection.

Apart from HBV infection, this virus induced hepatocarcinogenesis is the most important aspect which has a direct correlation with its life cycle and its $17 \mathrm{KDa}$ molecular weight HBV x protein (HBx) (Figure. 1). The genomic integration of $\mathrm{HBV}$ virus causes multiple effects such as chromosomal instability, copy number variations, aberrant expression of nearby genes and interruption of normal function. Previous studies reported that HBV preferentially incorporated into TERT, CCNE1, FAR2, ITRP1, IRAK2, MAPK1, MLL2 and MLL4 to cause aberrant expression for liver cancer. ${ }^{21-26}$ With the help of next generation sequencing (NGS), more comprehensive pictures of $\mathrm{HBV}$ integration into human chromosomes are revealed. Whole genome wide studies of HBV induced HCC patient samples revealed that the virus integration is occurring in both tumor and normal cells in hepatic tissue. ${ }^{27,28} \mathrm{HBV}$ integration was predominantly detected at chromosome 10 in the tumors whereas random distribution was observed in normal tissues. ${ }^{21}$ Notably, HBV integrations are predominantly occurred at enhancer, transcription factor binding sites and exon regions to induce genomic and transcriptomic aberrations in the tumors. ${ }^{16,27,29}$ Also, recurrent integration around $31-40 \%$ has been detected in tumor areas in certain genes that are predominantly associated with cell communication, differentiation, transcriptional regulation and negative regulation of cell death. ${ }^{16,27}$ Furthermore, non allelic recombination between two copies of integrated viral sequences causes genomic instability and loss of pro-apoptotic associated genes. ${ }^{29}$ Contrary to this, viral integrations were detected in intronic 


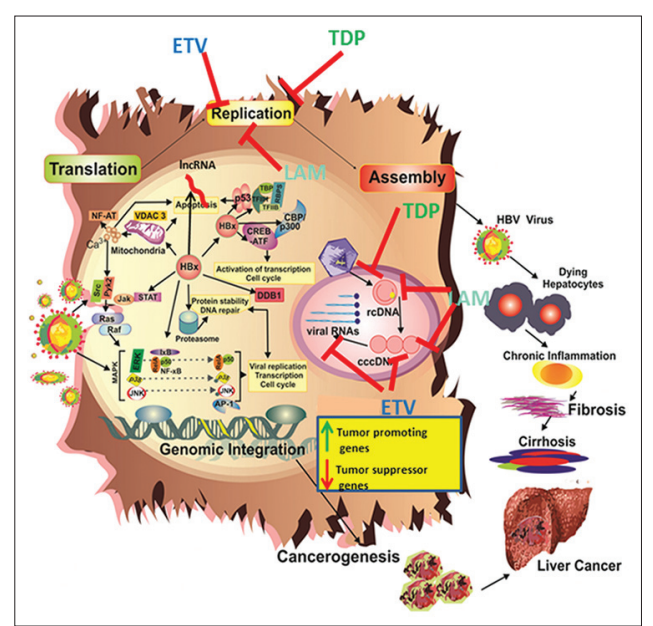

Figure 1: Molecular insight of HBV life cycle to induce HCC and novel antiviral therapies to alleviate liver cancer. Hepatotrophic HBV infects hepatocytes to initiate its pathogenic life cycle inside the host. During the initiation of infection of the liver by HBV, both linear DNA and rcDNA are converted into cccDNA. The cccDNA is transcribed into mRNA by host cell RNA polymerase II.The mRNA is translated into structural proteins (envelope and core proteins) and non-structural proteins (enzymes). Also, HBV virus undergoes genomic integration to regulate tumor promoting and suppressor genes to induce HCC. Sustained viral infection promotes chronic inflammation in hepatic microenvironment to drive sequentially fibrosis to cirrhosis to liver cancer. Therapeutically, third-generation nucleotides analogues (tenofovir and entecavir) maintained superior viral suppression in long-term therapies post tumor resection to first-generation drug (lamivudine). These drugs are inhibiting viral replication by chain terminator to inhibit DNA synthesis or interfere with priming or acts as a competitive inhibitor of dGTP. cccDNA, Covalently closed circular DNA; rcDNA, Relaxed circular DNA; HBx, Hepatitis B virus X protein; LAM, Lamivudine; ETV, Entecavir; TDP, Tenofovirdisoproxil phosphate; IncRNA, Long non coding RNA.

regions in normal tissues that might explain a favorable clonal expansion of most integrated positive hepatocytes in tumor areas. ${ }^{27}$

Besides genomic integration, the multifunctional regulatory protein HBx plays central role for the pathogenesis of HBV-induced hepatocarcinogenesis. During HBV integration into host genome, approximately $40 \%$ of breakpoints on the HBV genome were detected around 1800- base pair region where HBx and core genes are located. ${ }^{27}$ Thus chimeric transcripts of $\mathrm{HBx}$ with human gene can be detected that might promote tumorigenic potential and corrupt tumor suppressors. One such chimeric transcript HBx-LINE1 was identified in 23.3\% of HBV associated HCC. ${ }^{30,31}$ Functional characterization of HBx-LINE1 revealed that it might have a role in metastasis by promoting epithelial-mesenchymal transition. Besides chimeric fusions the classical oncoprotein $\mathrm{HBx}$ can modulate cell proliferation, apoptosis, migration, cell cycle progression and epigenetic regulationsdue to its prolonged expression ${ }^{32,33}$ (Figure 1). The HBx protein is a dual-specificity activator of transcription, stimulating signal transduction pathways in the cytoplasm and transcription factors in the nucleus. ${ }^{34}$ Extensive studies on the functional roles of $\mathrm{HBx}$ showed its transactivation property to upregulate viral and cellular genes including enhancers, class II and III promoters and proto-oncogenes through a wide variety of cis-elements. ${ }^{34}$ Cytoplasmic protein interaction with $\mathrm{HBx}$ has been shown to induce numerous signal transduction pathways such as NF-KB, ${ }^{35,36} \mathrm{NFAT},{ }^{37}$ RAS/RAF/MAPK, ${ }^{38}$ JAK-STAT, ${ }^{39,40} \mathrm{Wnt} / \beta$-catenin ${ }^{41}$ and anti-apoptotic activity by inhibiting p53 dependent activities $^{42}$ and modulating the serine proteases hepsin activities $^{43}$ and activation of surviving ${ }^{44}$ (Figure. 1). Inside the nucleus, $\mathrm{HBx}$ interferes with epigenetic changes by directly regulating DNA methyl transferase-3A and histone deacetylase- $1,{ }^{45,46}$ DNA repair mechanism ${ }^{47}$ and cell cycle related kinases ${ }^{48}$ to promote hepatocarcinogenesis (Figure 1). Furthermore, recent characterization of HBx interaction with miR-148, ${ }^{49}$ long noncoding RNA$\operatorname{Drch}^{50}$ and ERK/CREB pathway to upregulate FOXM1 expression ${ }^{51}$ provides a better insight about the functional role of HBx in invasiveness and metastasis of HCC. Overall, the recent findings on the functional role of HBx protein and HBV induced genomic changes greatly improved our therapeutic strategy to alleviate HBV driven liver cancer.

\section{Therapeutic approaches towards HBV induced HCC} The objective of HBV treatment is to prevent cirrhosis, liver degeneration and hepatocellular carcinoma. The paradigm of anti-viral therapy is continuously improving with an emphasis on long-term viral suppression, targeted, potent, minimal toxicity, suitable biomarker and less chance to emerge drug resistant mutant HBV strain. ${ }^{52-57}$ Vaccination for HBV is the most common mode of prevention. However, it has certainlimitations as several patient populations are noted to have suboptimal seroprotective rates after $\mathrm{HBV}$ vaccination. ${ }^{58}$

Presently, surgical resection along with concomitant antiviral therapy is considered suitable therapeutic strategy to reduce viral load and alleviate liver inflammation for extending the overall survival of HBV induced HCC patients. In case of antiviral treatment, there are several approved therapeutic medications like cytokine based therapy (interferon- $\alpha$ $(\mathrm{IFN}-\alpha)$ and pegylated IFN- $\alpha$ ) and nucleotide/nucleoside analogues (lamivudine, adefovirdipivoxil, entecavir, telbivudine, tenofovir and clevudine). The selection of specific treatment is based on patient characteristics and stage of the disease. Clinical studies showed that IFN- $\alpha$ based treatment causes higher rate of HBsA gloss among patients having HBV genotype A due to its immunomodulation. Also, lack of drug resistant viral strain and sustained seroconversion facilitate the overall survival period of HCC patients in this therapy. ${ }^{59,}{ }^{60}$ However, IFN- $\alpha$ has certain side effects- short plasma half-life that was improved by 
using pegylated-IFN- $\alpha$. Moreover, doses of 5-10 MU might cause influenza like symptom and organ toxicities-central nervous system disturbances, thyroid dysfunction and blood cytopenias. ${ }^{61}$ Modified version peg-IFN- $\alpha$ showed improved therapeutic efficacy and more suitable dose regimen. ${ }^{62}$ Based on large scale randomized studies, pegIFN- $\alpha$ therapy exhibited considerable loss of HBV DNA $(\sim 25 \%)$, significant amount of $\mathrm{HBeAg}$ seroconversion ( $20-32 \%$ ), optimal viral suppression maintained (a mean of $\sim 3 \mathrm{yrs})$ and a higher clearance rate of $\operatorname{HBsAg}(\sim 6 \%)$. ${ }^{63-}$

${ }^{66}$ Moreover, peg-IFN- $\alpha$ therapy for 52 weeks showed significant sustained virological responses in patients $(25 \%)$ having advanced fibrosis compared to without fibrosis $(12 \%)$ and cirrhotic patients $(30 \%)$ compared to without cirrhosis $(14 \%) .{ }^{67}$ Despite lot of advantages of peg-IFN- $\alpha$ therapy, this is not widely approved for HBV treatment due to its limited specificity towards genotype A and B of HBV and substantial side effects. Thus, IFN- $\lambda$ could be clinically beneficial for non-responding patients towards peg-IFN- $\alpha$ therapyafter its successful inhibition of HBV replication inpreclinical model. ${ }^{68,69}$ These immunomodulatory based cytokine therapies showed an important step towards therapy of HBV induced HCC patients. However, persistence HBV infection causes downregulation of RIG-1 mediated innate immunity and upregulation of immunosuppressive cytokines- transforming growth factor- $\beta$ and interleukin- $10 .^{70}$

From clinical data obtained from these chronic HBV patients, it was concluded that HBV specific T cells are either deleted or exhausted and there is substantial increase of immunosuppressive regulatory $\mathrm{T}$ cells. ${ }^{71,72}$ These could be a potential explanation of the limited success of IFN based therapy or vaccination approach for chronic HBV patients. To reactivate adoptive immune system, T-cell receptor gene transfer technique and HBV antigen-pulsed monocyte-derived dendritic cells could be used as an emerging therapy for lysing $\mathrm{HBV}$ infected hepatocytes that express viral antigens. ${ }^{52,73,74}$

Immune activation based therapies are important aspect to alleviate HBV related HCC by increasing sustained virological response, baseline ALT value and histological improvements. However HBV reactivation is frequently occurred in patients with baseline HBV replication status. Antiviral therapies are considered to reduce viral load and ameliorate hepatic inflammation to improve postoperative survival benefit. The first approved drug lamivudine showed seroconversion in both $\mathrm{HBeAg}$ positive and negative patients around $44-47 \%$ approximately and 56\% respectively after $2-5$ years of lamivudine therapy. ${ }^{75-77}$ The results of this study clearly suggested that lamivudine treatment improved the overall survival of patients but not recurrence free survival after radical hepatectomy in these patients. Based on Sung et al meta-analysis of 5 studies $(n=2289)$ suggested that lamivudine therapy greatly reduced the risk of HCC in 78\% of treated patients and this drug acts more effectively on patients without cirrhosis than with cirrhosis. ${ }^{78}$ Though, this drug showed amelioration of fibrosis and decrease the incidence of liver cancer, long-term therapy causes drug resistant $\mathrm{HBV}$ strain. Also, HBV reactivation was also detected in $>50 \%$ patients during post-therapeutic period. . $^{7,80}$

Due to various deleterious side effects of lamivudine, alternative antiviral drugs were explored with lower risk of drug resistance, more potent and affordable for longterm use. Clinical trial evaluations of several nucleoside and nucleotide analogs identified adefovirdipivoxil, entecavir, telbivudine, tenofovir and clevudine to consider superior antiviral agents to lamivudine. Based on the clinical experiences with these drugs, tenofovir and entecavir are considered the most potent first-line monotherapies for treating $\mathrm{CHB}$ and its associated HCC patients. Mechanistically, both of these drugs, tenofovir and entecavir, undergo phosphorylation multiple times by human cellular kinases to transform into their active metabolite with a half-life of 95 and 15 hrs respectively. ${ }^{81}$ Both drugs showed virological response rate around 95\% with minimal drug-resistant, well-tolerated and superior safety profile upon long-term therapy.

The long-term therapy with tenofovirdisoprpxilfumarate (TDF) is showing promising results for reducing the risk of HCC in CHB infected patients. In a large-scale study with 641 patients treated with TDF for 6 years showed that the incidence of HCC is reduced compared to predicted HCC risk. ${ }^{82}$ Also, there was a progressive divergence occurred between the predicted and observed number of HCC incidences after 3.3 years of follow-up with a standardized incidence ratio of $0.55(95 \% \mathrm{CI})$ at the latest follow-up (median 5.52 years).

In another two prospective studies of Tenofovir where patients were showing phenotypic and genotypic resistances towards adenovir or lamivudine or bothretain significant activity against $\mathrm{HBV}^{83,}{ }^{84}$ Patients in one of these studies had resistance to multiple nulceotides- lamivudine and adefovirdipivoxil ( $\sim 40 \%)$, lamivudine, adefovirdipivoxil and entecavir $(\sim 60 \%) .{ }^{83}$ Tenofovir containing treatment regimen for 12 and 24 months in these patients showed complete virologic response (serum HBV DNA level $\leq 60 \mathrm{IU} / \mathrm{mL}$ ) of $86.2 \%$ and $96.6 \%$ respectively. In other clinical trial, $63 \%$ patients had adefovirdipivoxil and $37 \%$ had adefovirdipivoxil and lamivudine resistance with a median duration of drug exposure between 2-3.5 years. ${ }^{84}$ Tenofovir containing mono or combination therapies for 96 weeks in these 60 enrolled patients achieved an undetectable viral load $<15 \mathrm{IU} / \mathrm{mL}$ 
in $64.4 \%$ of cases. Given these clinical results, it can be concluded that tenofovir can be administered either as monotherapy or rescue therapy where first line of antiviral treatment did not show any improvement.

The effect of third-generation drug entecavir showed lot of promising results on HBV related cirrhotic patients with a risk of liver cancer. One retrospective-prospective cohort clinical study was conducted with 1446 entecavir-treated patients with a follow-up for $36 \pm 13$ months. ${ }^{85}$ Overall, there was no significant difference in hepatic events between entecavir-treated patients compared to control cohorts. Nevertheless, entecavir-treatment significantly reduced the risk of HCC in $78 \%$ of the 482 cirrhotic patients compared to untreated patients. Compared to tenofovir, entecavir was unable to achieve viral suppression in patients who previously received antiviral drug therapies- lamivudine, adefovir, telbivudine or cytokine based therapy peg-IFN- $\alpha$.

Both tenofovir and entecavir are able to achieve long-term response against virus with low rates of viral breakthrough and well-tolerated among patients except tenofovir treatment showed nephrotoxicity. ${ }^{86,87}$ However, superior therapeutic efficacy between tenofovir and entecavir is not widely studied in clinical trials. One retrospective case-control study was conducted to compare between 62 patients treated with tenofovir and 199 patients treated with entecavir. ${ }^{88}$ Though there is no significant difference in rates of viral suppression, tenofovir treated patients achieved viral suppression faster (16\% at 6 months, $50 \%$ at 12 months, and $71 \%$ at 18 months) than those taken entecavir (11\% at 6 months, $13 \%$ at 12 months, and $39 \%$ at 18 months). This study is definitely recommending for tenofovir as a suitable medication for HBV induced HCC however more worldwide studies especially patients with genotypic variations are required for definitive recommendation. Apart from these two drugs with extensive clinical trials, a new antiviral pyrimidine nucleoside analogue clevudine has been approved in South Korea. ${ }^{89}$ Initial multicenter clinical trials demonstrated that daily dose of $30 \mathrm{mg}$ for 24 weeks maintained virologic response in $59 \%$ of $\mathrm{HBeAg}$ positive and $92 \%$ in $\mathrm{HBeAg}$ negative $\mathrm{CHB}$ patients without any viral breakthrough. ${ }^{53,90}$ In another retrospective study, clevudine therapy showed comparable ALT normalization of $83.9 \%$ at 48 weeks and $91.5 \%$ at 96 weeks to entecavir treated patients $80.9 \%$ and $91.2 \%$ respectively. ${ }^{11}$ Also, serum HBV DNA level was lowered in $72.6 \%$ and $83.1 \%$ in clevudine treated group compared to entecavir treatment group $74.4 \%$ and $83.8 \%$ respectively during the same time points. The initial outcomes of clevudine therapy are as good as entecavir upto 96 weeks study. More long-term and rescue therapies are required to understand its optimal clinical efficacy. In this review we have also provided updated results of completed clinical trials in Table 1 which might be a better opportunity for HBV infected HCC patients in near future.

\section{CONCLUSION}

Over the last decade several seminal studies have provided numerous breakthroughs in molecular pathogenesis of HBV related liver cancer and its effective management strategies. Extensive genomic sequencing of $\mathrm{HBV}$ induced HCC patients have suggested the complexity of HBV infection and its targeted multiple signaling pathways that

\begin{tabular}{|c|c|c|c|c|}
\hline Drug name & $\begin{array}{l}\text { Type } \\
\text { of CLD }\end{array}$ & $\begin{array}{l}\text { Phase } \\
\text { of trial }\end{array}$ & Outcome of trial & References \\
\hline $\begin{array}{l}\text { HBsAg-HBIG immunogenic complex } \\
\text { therapeutic vaccine }\end{array}$ & HBV & III & $\begin{array}{l}\text { HBeAg seroconversion is decreased. Overdosing } \\
\text { caused immune fatigue }\end{array}$ & {$[83]$} \\
\hline Besifovir & HBV & $\mathrm{Ilb}$ & Similar effect as entecavir & {$[84]$} \\
\hline HEPLISAV & HBV & III & Complete seroprotection after three doses & $\begin{array}{l}\text { Dynavax } \\
\text { Technologies }\end{array}$ \\
\hline NASVAC & HBV & III & $\begin{array}{l}\text { Complete seroconversion as early as in } 30 \text { days and } \\
\text { serprotection with highest a-HBs titer at day } 90\end{array}$ & $\begin{array}{c}{[85],} \\
\text { NCT01374308 }\end{array}$ \\
\hline Molixan & HBV & II/III & $\begin{array}{l}\text { Immunomodulating and } \\
\text { anti-inflammatory. More than } 700 \text { Russian patients } \\
\text { were treated successfully }\end{array}$ & {$[86]$} \\
\hline $\begin{array}{l}\text { X-linked inhibitor of apoptosis (XIAP) } \\
\text { antisensense AEG3515 and sorafenib }\end{array}$ & $\mathrm{HCC}$ & II & More promising than sorafenib alone & {$[87]$} \\
\hline Tivantinib & $\mathrm{HCC}$ & II & $\begin{array}{l}\text { Potential alternative option for advanced HCC } \\
\text { patients }\end{array}$ & [88] \\
\hline Sorafenib and Gemcitabine & $\mathrm{HCC}$ & II & Not better than sorafenib alone & [89] \\
\hline Sorafenib and Tegafur/Uracil & $\mathrm{HCC}$ & II & More efficacious than sorafenib alone & [90] \\
\hline MGN-3 with interventional therapy & $\mathrm{HCC}$ & II & Useful for the treatment of $\mathrm{HCC}$ & [91] \\
\hline Pegylated Arginine deiminase & $\mathrm{HCC}$ & II & Promising and well tolerated & {$[92]$} \\
\hline $\begin{array}{l}\text { TRC105 anti-angiogenic monoclonal } \\
\text { Antibody }\end{array}$ & $\mathrm{HCC}$ & II & $\begin{array}{l}\text { Well tolerated in patients. Suitable as a combination } \\
\text { therapy }\end{array}$ & [93] \\
\hline 5-fluorouracil/leucovorin (FOLFOX4) & $\mathrm{HCC}$ & III & Increased response rate and median overall survival & [94] \\
\hline
\end{tabular}


drive tumor progression. Also, the protein $\mathrm{HBx}$ regulates in cis- and trans- tumor promoting and suppressor proteins which are often found to play critical roles in early tumorigenesis and development. Parallel to molecular insights, long-term therapy with immunomodulators or nucleotide analogues or in combinations showed significant viral suppression in numerous clinical trials. The treatment by high genetic barrier nucleotide analogues is highly beneficial to HBV patients with high baseline risk of cirrhosis. In addition these next generation nucleotide analogues promote virological remission in patients, thereby reducing the risk of HCC. Along with therapeutic advancements there is also a serious requirement of global multicenter clinical trials among different ethnic groups and compilation of the results to predict drug efficacy.

\section{HIGHLIGHTS}

- HBV mediated liver infection is affecting approximately billion of people across the world based on hepatitis foundation.

- Approximately $75-80 \%$ of HCC cases are associated with chronic infection of HBV.

- Whole genomic sequencing analysis revealed lot of new insights about the HBV induced HCC

- This review provides the latest promising results of clinical trials and long term therapies with tenofovir,entecavir and clevudine for HBV induced HCC patients.

\section{REFERENCES}

1. McClune AC and Tong MJ. Chronic hepatitis B and hepatocellular carcinoma. Clin Liver Dis 2010;14: 461-476.

2. Ghabeshi S, Sharifi Z, Hosseini SM and Mahmoodian Shooshtari M. Correlation between viral load of HBV in chronic hepatitis B patients and precore and Basal core promoter mutations. Hepat Mon 2013;13: e7415.

3. Lavanchy D. Hepatitis B virus epidemiology, disease burden, treatment, and current and emerging prevention and control measures. Journal of viral hepatitis 2004;11: 97-107.

4. Chatterjee R and Mitra A. An overview of effective therapies and recent advances in biomarkers for chronic liver diseases and associated liver cancer. International immunopharmacology 2015.

5. Hou J, Liu Z and Gu F. Epidemiology and Prevention of Hepatitis B Virus Infection. Int J Med Sci 2005;2: 50-57.

6. Elizabeth W and Hwang RC. Global Epidemiology of Hepatitis B Virus (HBV) Infection. The North American Journal of Medicine and Science 2011;4: 7-13.

7. Hiotis SP, Rahbari NN, Villanueva GA, Klegar E, Luan W, Wang $Q$, et al. Hepatitis B vs. hepatitis C infection on viral hepatitis-associated hepatocellular carcinoma. BMC Gastroenterol 2012;12: 64.

8. Basu PaBJ, R. Entecavir for treatment of chronic hepatitis B: A clinical update for the treatment of patients with decompensated cirrhosis. Open Journal of Internal Medicine 2012;2: 53-61.

9. Yang HI, Lu SN, Liaw YF, You SL, Sun CA, Wang LY, et al.
Hepatitis B e antigen and the risk of hepatocellular carcinoma N Engl J Med 2002;347: 168-174.

10. Yan H, Zhong G, Xu G, He W, Jing Z, Gao Z, et al. Sodium taurocholate cotransporting polypeptide is a functional receptor for human hepatitis B and D virus. Elife 2012;1: e00049.

11. Ott JJ, Stevens GA, Groeger J and Wiersma ST. Global epidemiology of hepatitis $B$ virus infection: new estimates of age-specific HBsAg seroprevalence and endemicity. Vaccine 2012;30: 2212-2219.

12. Di Bisceglie AM. Hepatitis $B$ and hepatocellular carcinoma. Hepatology 2009;49: S56-S60.

13. Grimm D, Thimme R and Blum HE. HBV life cycle and novel drug targets. Hepatol Int 2011;5: 644-653.

14. Lin $\mathrm{YJ}, \mathrm{Wu} \mathrm{HL}$, Chen DS and Chen PJ. Hepatitis $B$ virus nucleocapsid but not free core antigen controls viral clearance in mice. J Virol 2012;86: 9266-9273.

15. Xu C, Zhou W, Wang $Y$ and Qiao L. Hepatitis B virus-induced hepatocellular carcinoma. Cancer Lett 2014;345: 216-222.

16. Li X, Zhang J, Yang Z, Kang J, Jiang S, Zhang T, et al. The function of targeted host genes determines the oncogenicity of HBV integration in hepatocellular carcinoma. Journal of hepatology 2013.

17. Nagaya $T$, Nakamura $T$, Tokino $T$, Tsurimoto $T$, Imai $M$, Mayumi $\mathrm{T}$, et al. The mode of hepatitis $\mathrm{B}$ virus DNA integration in chromosomes of human hepatocellular carcinoma. Genes Dev 1987; 1: 773-782.

18. Schmitz A, Schwarz A, Foss M, Zhou L, Rabe B, Hoellenriegel J, et al. Nucleoporin 153 arrests the nuclear import of hepatitis $B$ virus capsids in the nuclear basket. PLoS Pathog 2010;6: e1000741.

19. Lucifora J, Xia Y, Reisinger F, Zhang K, Stadler D, Cheng X, et al. Specific and nonhepatotoxic degradation of nuclear hepatitis $B$ virus cccDNA. Science 2014;343: 1221-1228.

20. Rabe B, Delaleau M, Bischof A, Foss M, Sominskaya I, Pumpens $P$, et al. Nuclear entry of hepatitis B virus capsids involves disintegration to protein dimers followed by nuclear reassociation to capsids. PLoS Pathog 2009;5: e1000563.

21. Toh ST, Jin Y, Liu L, Wang J, Babrzadeh F, Gharizadeh B, et al. Deep sequencing of the hepatitis $B$ virus in hepatocellular carcinoma patients reveals enriched integration events, structural alterations and sequence variations. Carcinogenesis 2013;34: 787-798.

22. Murakami $Y$, Saigo K, Takashima H, Minami M, Okanoue $T$, Brechot C, et al. Large scaled analysis of hepatitis B virus (HBV) DNA integration in HBV related hepatocellular carcinomas. Gut 2005;54: 1162-1168.

23. Paterlini-Brechot $P$, Saigo K, Murakami $Y$, Chami M, Gozuacik D, Mugnier C, et al. Hepatitis B virus-related insertional mutagenesis occurs frequently in human liver cancers and recurrently targets human telomerase gene. Oncogene 2003;22: 3911-3916.

24. Gozuacik D, Murakami Y, Saigo K, Chami M, Mugnier C, Lagorce $D$, et al. Identification of human cancer-related genes by naturally occurring Hepatitis B Virus DNA tagging. Oncogene 2001;20: 6233-6240.

25. Saigo K, Yoshida K, Ikeda R, Sakamoto $Y$, Murakami $Y$, Urashima $T$, et al. Integration of hepatitis $B$ virus DNA into the myeloid/lymphoid or mixed-lineage leukemia (MLL4) gene and rearrangements of MLL4 in human hepatocellular carcinoma Human mutation 2008;29: 703-708.

26. Chang L, Graham PH, Hao J, Ni J, Bucci J, Cozzi PJ, et al. Acquisition of epithelial-mesenchymal transition and cancer stem cell phenotypes is associated with activation of the PI3K/ Akt/mTOR pathway in prostate cancer radioresistance. Cell death \& disease 2013;4: e875. 
27. Sung WK, Zheng H, Li S, Chen R, Liu X, Li Y, et al. Genome-wide survey of recurrent HBV integration in hepatocellular carcinoma. Nature genetics 2012;44: 765-769.

28. Mitra A, Satelli A, Xia X, Cutrera J, Mishra L and Li S. Cell-surface Vimentin: A mislocalized protein for isolating csVimentin CD133 novel stem-like hepatocellular carcinoma cells expressing EMT markers. International journal of cancer Journal international du cancer 2014.

29. Jiang Z, Jhunjhunwala S, Liu J, Haverty PM, Kennemer MI, Guan Y, Lee W, et al. The effects of hepatitis B virus integration into the genomes of hepatocellular carcinoma patients. Genome Res 2012;22: 593-601.

30. Lau CC, Sun T, Ching AK, He M, Li JW, Wong AM, et al. Viralhuman chimeric transcript predisposes risk to liver cancer development and progression. Cancer Cell 2014;25: 335-349.

31. Mitra A, Mishra L and Li S. Technologies for deriving primary tumor cells for use in personalized cancer therapy. Trends in biotechnology 2013;31: 347-354.

32. You X, Liu F, Zhang T, Lv N, Liu Q, Shan C, et al. Hepatitis B virus $X$ protein upregulates Lin28A/Lin28B through Sp-1/CMyc to enhance the proliferation of hepatoma cells. Oncogene 2014;33: 449-460.

33. Tian $Y$, Yang $W$, Song $J, W u ~ Y$ and Ni B. Hepatitis B virus $X$ protein-induced aberrant epigenetic modifications contributing to human hepatocellular carcinoma pathogenesis. Mol Cell Biol 2013;33: 2810-2816.

34. $\mathrm{Ng} \mathrm{SA}$ and Lee $\mathrm{C}$. Hepatitis $\mathrm{B}$ virus $\mathrm{X}$ gene and hepatocarcinogenesis. J Gastroenterol 2011;46: 974-990.

35. Bui-Nguyen TM, Pakala SB, Sirigiri RD, Xia W, Hung MC, Sarin SK, et al. NF-kappaB signaling mediates the induction of MTA1 by hepatitis $B$ virus transactivator protein $\mathrm{HBx}$. Oncogene 2010;29: 1179-1189.

36. Nagy ZS, LeBaron MJ, Ross JA, Mitra A, Rui H and Kirken RA. STAT5 regulation of BCL10 parallels constitutive NFkappaB activation in lymphoid tumor cells. Molecular cancer 2009;8: 67 .

37. Carretero M, Gomez-Gonzalo M, Lara-Pezzi E, Benedicto I, Aramburu J, Martinez-Martinez S, et al. The hepatitis B virus $X$ protein binds to and activates the $\mathrm{NH}(2)$-terminal transactivation domain of nuclear factor of activated T cells-1. Virology 2002;299: 288-300.

38. Doria M, Klein N, Lucito R and Schneider RJ. The hepatitis B virus $\mathrm{HBx}$ protein is a dual specificity cytoplasmic activator of Ras and nuclear activator of transcription factors. EMBO J 1995; 14: 4747-4757.

39. Arbuthnot $P$, Capovilla $A$ and Kew M. Putative role of hepatitis $B$ virus $X$ protein in hepatocarcinogenesis: effects on apoptosis, DNA repair, mitogen-activated protein kinase and JAK/STAT pathways. J Gastroenterol Hepatol 2000;15: 357-368.

40. Mitra A, Ross JA, Rodriguez G, Nagy ZS, Wilson HL and Kirken RA. Signal transducer and activator of transcription 5b (Stat5b) serine 193 is a novel cytokine-induced phosphoregulatory site that is constitutively activated in primary hematopoietic malignancies. The Journal of biological chemistry 2012;287: 16596-16608.

41. Cha MY, Kim CM, Park YM and Ryu WS. Hepatitis B virus $X$ protein is essential for the activation of Wnt/beta-catenin signaling in hepatoma cells. Hepatology 2004;39: 1683-1693.

42. Knoll S, Furst K, Thomas S, Villanueva Baselga S, Stoll A, Schaefer $S$, et al. Dissection of cell context-dependent interactions between $\mathrm{HBx}$ and p53 family members in regulation of apoptosis: a role for HBV-induced HCC. Cell Cycle 2011;10: 3554-3565.

43. Zhang JL, Zhao WG, Wu KL, Wang K, Zhang X, Gu CF, et al. Human hepatitis $B$ virus $X$ protein promotes cell proliferation and inhibits cell apoptosis through interacting with a serine protease Hepsin. Arch Virol 2005;150: 721-741.

44. Marusawa H, Matsuzawa S, Welsh K, Zou H, Armstrong R, Tamm I, et al. HBXIP functions as a cofactor of survivin in apoptosis suppression. EMBO J 2003;22: 2729-2740.

45. Okamoto Y, Shinjo K, Shimizu Y, Sano T, Yamao K, Gao W, et al. Hepatitis virus infection affects DNA methylation in mice with humanized livers. Gastroenterology 2014;146: 562-572.

46. Zheng DL, Zhang L, Cheng N, Xu X, Deng Q, Teng XM, et al. Epigenetic modification induced by hepatitis $B$ virus $X$ protein via interaction with de novo DNA methyltransferase DNMT3A. Journal of hepatology 2009;50: 377-387.

47. van de Klundert MA, van Hemert FJ, Zaaijer HL and Kootstra NA. The hepatitis $B$ virus $x$ protein inhibits thymine DNA glycosylase initiated base excision repair. PLoS One 2012;7: e48940.

48. Yu Z, Gao YQ, Feng H, Lee YY, Li MS, Tian Y, et al. Cell cycle-related kinase mediates viral-host signalling to promote hepatitis B virus-associated hepatocarcinogenesis. Gut 2014.

49. Xu X, Fan Z, Kang L, Han J, Jiang C, Zheng X, et al. Hepatitis B virus $X$ protein represses miRNA-148a to enhance tumorigenesis. J Clin Invest 2013;123: 630-645.

50. Huang JF, Guo YJ, Zhao CX, Yuan SX, Wang Y, Tang GN, et al. Hepatitis $B$ virus $X$ protein $(\mathrm{HBx})$-related long noncoding RNA (IncRNA) down-regulated expression by HBx (Dreh) inhibits hepatocellular carcinoma metastasis by targeting the intermediate filament protein vimentin. Hepatology 2013;57: 1882-1892.

51. Xia L, Huang $W$, Tian D, Zhu $H$, Zhang $Y, H u ~ H$, et al. Upregulated FoxM1 expression induced by hepatitis $B$ virus $X$ protein promotes tumor metastasis and indicates poor prognosis in hepatitis B virus-related hepatocellular carcinoma. Journal of hepatology 2012;57: 600-612.

52. Wood NJ. Immunotherapy: Therapeutic potential of genetically modified HBV-specific T cells for chronic HBV infection and HBV-related HCC. Nat Rev Gastroenterol Hepatol 2011;8: 61.

53. Yoo BC, Kim JH, Kim TH, Koh KC, Um SH, Kim YS, et al. Clevudine is highly efficacious in hepatitis $B$ e antigen-negative chronic hepatitis B with durable off-therapy viral suppression. Hepatology 2007;46: 1041-1048.

54. Grammatikos G, Ferreiros N, Bon D, Schwalm S, Dietz J, Berkowski $\mathrm{C}$, et al. Variations in serum sphingolipid levels associate with liver fibrosis progression and poor treatment outcome in HCV but not HBV infection. Hepatology 2014.

55. Satelli A, Brownlee Z, Mitra A, Meng QH and Li S. Circulating Tumor Cell Enumeration with a Combination of Epithelial Cell Adhesion Molecule- and Cell-Surface Vimentin-Based Methods for Monitoring Breast Cancer Therapeutic Response. Clinical chemistry $2014 ; 61: 259-266$

56. Satelli A, Mitra A, Cutrera JJ, Devarie M, Xia X, Ingram DR, et al. Universal marker and detection tool for human sarcoma circulating tumor cells. Cancer Res 2014;74: 1645-1650.

57. Mitra A, Satelli A, Yan J, Xueqing X, Gagea M, Hunter CA, et al. IL-30 (IL27p28) attenuates liver fibrosis through inducing NKG2D-rae1 interaction between NKT and activated hepatic stellate cells in mice. Hepatology 2014. 60:2027-2039.

58. Seto WK, Fung J, Yuen MF and Lai CL. Future prevention and treatment of chronic hepatitis B infection. J Clin Gastroenterol 2012;46: 725-734.

59. van Zonneveld M, Honkoop P, Hansen BE, Niesters HG, Darwish Murad S, de Man RA, et al. Long-term follow-up of alpha-interferon treatment of patients with chronic hepatitis $B$. Hepatology 2004;39: 804-810.

60. Yuen MF, Hui CK, Cheng CC, Wu CH, Lai YP and Lai CL. Longterm follow-up of interferon alfa treatment in Chinese patients with chronic hepatitis B infection: The effect on hepatitis B e 
antigen seroconversion and the development of cirrhosis-related complications. Hepatology 2001;34: 139-145.

61. Perrillo R. Benefits and risks of interferon therapy for hepatitis $B$. Hepatology 2009;49: S103-S111.

62. Ayoub WS and Keeffe EB. Review article: current antiviral therapy of chronic hepatitis B. Alimentary pharmacology \& therapeutics 2011;34: 1145-1158.

63. Li WC, Wang MR, Kong LB, Ren WG, Zhang YG and Nan YM. Peginterferon alpha-based therapy for chronic hepatitis $\mathrm{B}$ focusing on $\mathrm{HBsAg}$ clearance or seroconversion: a meta-analysis of controlled clinical trials. BMC Infect Dis 2011;11: 165

64. Ratnam D, Dev A, Nguyen T, Sundararajan V, Harley $H$, Cheng W, et al. Efficacy and tolerability of pegylated interferonalpha-2a in chronic hepatitis B: a multicenter clinical experience. J Gastroenterol Hepatol 2012;27: 1447-1453.

65. Buster EH, Flink HJ, Cakaloglu Y, Simon K, Trojan J, Tabak F, et al. Sustained $\mathrm{HBeAg}$ and $\mathrm{HBsAg}$ loss after long-term followup of $\mathrm{HBeAg}$-positive patients treated with peginterferon alpha2b. Gastroenterology 2008;135: 459-467.

66. Janssen HL, van Zonneveld M, Senturk H, Zeuzem S, Akarca US, Cakaloglu $Y$, et al. Pegylated interferon alfa-2b alone or in combination with lamivudine for $\mathrm{HBeAg}$-positive chronic hepatitis B: a randomised trial. Lancet 2005;365: 123-129.

67. Buster EH, Hansen BE, Buti M, Delwaide J, Niederau C, Michielsen PP, et al. Peginterferon alpha- $2 b$ is safe and effective in $\mathrm{HBeAg}$-positive chronic hepatitis $\mathrm{B}$ patients with advanced fibrosis. Hepatology 2007;46: 388-394.

68. Robek MD, Boyd BS and Chisari FV. Lambda interferon inhibits hepatitis B and C virus replication. J Virol 2005;79: 3851-3854.

69. Nakagawa S, Hirata $\mathrm{Y}$, Kameyama T, Tokunaga $\mathrm{Y}$, Nishito $\mathrm{Y}$, Hirabayashi K, et al. Targeted induction of interferon-lambda in humanized chimeric mouse liver abrogates hepatotropic virus infection. PLoS One 2013;8: e59611.

70. Lan P, Zhang C, Han Q, Zhang J and Tian Z. Therapeutic recovery of hepatitis $B$ virus (HBV)-induced hepatocyte-intrinsic immune defect reverses systemic adaptive immune tolerance. Hepatology 2013;58: 73-85.

71. Gehring AJ, Ho ZZ, Tan AT, Aung MO, Lee KH, Tan KC, et al. Profile of tumor antigen-specific CD8 T cells in patients with hepatitis B virus-related hepatocellular carcinoma. Gastroenterology 2009;137: 682-690.

72. Zhang $\mathrm{HH}$, Mei MH, Fei R, Liu F, Wang JH, Liao WJ, et al. Regulatory $T$ cells in chronic hepatitis $B$ patients affect the immunopathogenesis of hepatocellular carcinoma by suppressing the anti-tumour immune responses. Journal of viral hepatitis 2010;17 Suppl 1: 34-43.

73. Shi M, Qian S, Chen WW, Zhang H, Zhang B, Tang ZR, et al. Hepatitis B virus (HBV) antigen-pulsed monocyte-derived dendritic cells from HBV-associated hepatocellular carcinoma patients significantly enhance specific $T$ cell responses in vitro. Clin Exp Immunol 2007;147: 277-286.

74. Gehring AJ, Xue SA, Ho ZZ, Teoh D, Ruedl C, Chia A, et al. Engineering virus-specific $T$ cells that target HBV infected hepatocytes and hepatocellular carcinoma cell lines. Journal of hepatology 2011;55: 103-110.

75. Chang TT, Lai CL, Chien RN, Guan R, Lim SG, Lee CM, et al. Four years of lamivudine treatment in Chinese patients with chronic hepatitis B. J Gastroenterol Hepatol 2004;19: 12761282.
76. Yao GB, Zhu M, Cui ZY, Wang BE, Yao JL and Zeng MD A 7-year study of lamivudine therapy for hepatitis B virus e antigen-positive chronic hepatitis B patients in China. J Dig Dis 2009;10: 131-137.

77. Fung SK, Wong F, Hussain M and Lok AS. Sustained response after a 2-year course of lamivudine treatment of hepatitis B e antigen-negative chronic hepatitis $B$. Journal of viral hepatitis 2004;11: 432-438.

78. Sung JJ, Tsoi KK, Wong VW, Li KC and Chan HL. Meta-analysis: Treatment of hepatitis $B$ infection reduces risk of hepatocellular carcinoma. Alimentary pharmacology \& therapeutics 2008;28: 1067-1077.

79. Kuo $\mathrm{YH}$, Chen $\mathrm{CH}$, Wang $\mathrm{JH}$, Hung $\mathrm{CH}$, Tseng $\mathrm{PL}$, Lu SN, et al. Extended lamivudine consolidation therapy in hepatitis $B$ e antigenpositive chronic hepatitis $B$ patients improves sustained hepatitis $B$ e antigen seroconversion. Scand J Gastroenterol 2010;45: 75-81.

80. Chien RN and Liaw YF. Short-term lamivudine therapy in HBeAg-negative chronic active hepatitis B in Taiwan. Antivir Ther 2006;11: 947-952.

81. De Clercq E, Ferir G, Kaptein S and Neyts J. Antiviral treatment of chronic hepatitis B virus (HBV) infections. Viruses 2010;2: 1279-1305.

82. Kim RW, Berg T, Loomba R, Aguilar Schall R, Dinh P, Yee LJ, et al. 43 Long term Tenfovir disoproxil fumarate (TDF) therapy and the risk of hepatocellular carcinoma. Journal of hepatology 2013;58: S1-S24.

83. Kim YJ, Sinn DH, Gwak GY, Choi MS, Koh KC, Paik SW, et al. Tenofovir rescue therapy for chronic hepatitis $B$ patients after multiple treatment failures. World journal of gastroenterology: WJG 2012;18: 6996-7002.

84. Patterson SJ, George J, Strasser SI, Lee AU, Sievert W, Nicoll AJ, et al. Tenofovir disoproxil fumarate rescue therapy following failure of both lamivudine and adefovir dipivoxil in chronic hepatitis B. Gut 2011;60: 247-254.

85. Wong GL, Chan HL, Mak CW, Lee SK, Ip ZM, Lam AT, et al. Entecavir treatment reduces hepatic events and deaths in chronic hepatitis B patients with liver cirrhosis. Hepatology 2013;58: 1537-1547.

86. Herlitz LC, Mohan S, Stokes MB, Radhakrishnan J, D'Agati VD and Markowitz GS. Tenofovir nephrotoxicity: acute tubular necrosis with distinctive clinical, pathological, and mitochondrial abnormalities. Kidney Int 2010;78: 1171-1177.

87. Perazella MA. Tenofovir-induced kidney disease: an acquired renal tubular mitochondriopathy. Kidney Int 2010;78: 1060-1063.

88. Gao L. THN, Li J., Li M and Nguyen H. Tenofovir Is More Effective Than Entecavir for Achieving Rapid Viral Suppression in HBeAg-Positive Chronic Hepatitis B Patients With High HBV DNA Levels. Digestive Disease Week 2013;Sa: 1009.

89. Jang JH, Kim JW, Jeong SH, Myung HJ, Kim HS, Park YS, et al. Clevudine for chronic hepatitis $\mathrm{B}$ : antiviral response, predictors of response, and development of myopathy. Journal of viral hepatitis 2011;18: 84-90.

90. Yoo BC, Kim JH, Chung YH, Lee KS, Paik SW, Ryu SH, et al. Twenty-four-week clevudine therapy showed potent and sustained antiviral activity in $\mathrm{HBeAg}$-positive chronic hepatitis $\mathrm{B}$. Hepatology 2007;45: 1172-1178.

91. Kim SB, Song IH, Kim YM, Noh R, Kang HY, Lee H, et al. Longterm treatment outcomes of clevudine in antiviral-naive patients with chronic hepatitis B. World journal of gastroenterology: WJG 2012;18: 6943-6950.

\footnotetext{
Authors Contribution:

RC - Literature search, manuscript design, writing and correcting; AM - Editing and modifying the manuscript.
} 